\title{
The Synthesis of Grameen Bank Microfinance Approaches in Bangladesh
}

\author{
Rafiqur Rahman (Corresponding author) \\ School of Economics and Management, Northwest A\&F University \\ 3, Taicheng Road, Yangling, Shaanxi712100, P.R.China \\ E-mail: ferdousbazar@gmail.com
}

Qiang Nie

Lecturer, School of Economics and Management, Northwest A\&F University

3, Taicheng Road, Yangling, Shaanxi712100, P.R.Chian

E-mail: nieqiang2007@163.com

Received: June 12, 2011

doi:10.5539/ijef.v3n6p207
Accepted: June 27, 2011

Published: November 1, 2011

URL: http://dx.doi.org/10.5539/ ijef.v3n6p207

\begin{abstract}
The paper briefly described the operational mechanism innovation of key Microfinance Service Providers (MSPs) in Bangladesh. Grameen Bank has chosen to examine the approaches of microfinance. Grameen Bank is dominating microfinance market in Bangladesh in outreach, outstanding loans, savings, and efficient selected delivery mechanism. They offer micro-credit, savings and social services to the poor who were deprived from such access offered by conventional banks. Grameen Bank of Bangladesh is known worldwide for its innovative credit delivery to the rural poor. The bank offers loans to poor particularly the women in groups of five in order to create peer social pressure and solidarity which seems to work well in a society where social networks are often of vital Importance. Grameen Bank has been able to demonstrate the effectiveness of microfinance programs towards sustainable development for the rural poor in Bangladesh. The present study contributes to the literature on diverse microfinance approaches. The study may lead to further methodological improvement of the microfinance institutions in Bangladesh and elsewhere. Finally, microfinance practitioners and policy makers might gain better understanding on existing microfinance approaches in Bangladesh and can think or re-think for adaptation.
\end{abstract}

Keywords: Microfinance approach, Bangladesh, Grameen Bank

\section{Introduction}

Bangladesh is the pioneer adapter of the microfinance modern concept in the world. Microfinance is the provision of micro-credit as well as savings, insurance, remittance, health, education, skill training, and social awareness etc. According to the United Nations definition, microfinance is loans, savings, insurances, transfer services and other financial products for low-income clients (UN, 2006). Unfortunately, the rural poor face a significant shortage of capital, and traditional financial institutions, with their impossible loan conditions, inaccessibility and bureaucracy, ignore the poorest of the poor (Yunus, 2007). So, a large number of Non-government Organization (NGOs) and Microfinance Institute (MFIs) have been sponsoring financial inclusion to the poor next to government in the world. Actually, microfinance has been helping the poor particularly the women in a community. Microfinance has served 150 million borrowers with 39 billion USD in loans and holding 22 billions USD in deposits from 67 million clients (MIX, 2010, Pacheco et el, 2010). Meanwhile, Microfinance Service Providers (MSPs) have developed and improved a good number of original methodologies and defined conventional wisdom to financing the poor with maintaining financial viability (Morduch 1999, CGPA, 2006). Bangladesh has one of the largest, most innovative and best known NGO and MFI communities in the world (DFID, 2010). It is worth to mention that, the approaches of Grameen Bank have crossed the national boundary and have been replicated by others nation. For their successful achievement, they have gained several prestigious awards from national and international organizations. For example, Grameen Bank and Prof. Dr. Mohammad Yunus jointly were awarded "Noble Peace" prize in 2006 and presidential award in 2010.

The present study aims to critically synthesize the approaches of Grameen Bank in Bangladesh. It is expected that the elaborate discussions on microfinance approaches of Grameen Bank might help microfinance practitioners, 
experts policy makers as well as service providers to recognize the activities of microfinance in a clear term and re-think about future plans, strategies and actions.

\section{Methodology}

The basic foundation of the study is relied on secondary sources of information. Primary sources of information are limited to personal observation and face-to-face interviews with several microfinance experts to strengthen the quality of the paper. The paper is descriptive in nature paying special attention on comparative features. Secondary information were gathered from published articles, conference proceedings, annual report, Microfinance Regulatory Authority (MRA) in Bangladesh, International Poverty Reduction Centre in China (IPRCC) and the websites of Grameen Bank.

\section{The background of the emergence of Grameen Bank}

The Grameen Bank started with the belief of an individual- a young economist visiting the famine driven rural communities of Bangladesh in 1974. Through a conversation encounter with a bamboo stool maker who was trapped in the vicious cycle of poverty, this young economist, by the name of Muhammed Yunus, discovered a dire condition and a dire need in Bangladesh (Dowla and Barua 15, 2006). As the high-interest rates offered by moneylenders, many rural areas were cursed by poverty. With a strong faith in the poor- a faith that they would repay on time without the threat of confiscation or collateral, and faith that they would know how to maximize the benefits of their loans without any training - Yunus decided to take action, lending \$27 of his own money to the villagers ( Dowla and Barua 3, 2006). As his \$27 loan was fully repaid, Yunus was more influenced that the people who were poor were equally ready and capable to repay loan on their own ingenuity. This is also believed by him that he had found a workable process that might help the poorest of the poor earn though self-starting.

Yunus applied the Grameen Bank project in 1976 as pilot basis in Jobra village (a village adjoining to Chittagong University, Bangladesh) as a trial to judge his belief on a large scale. The research project was examining the possibility of designing a credit delivery system to provide banking services targeted at the rural poor. The bank primarily restricted its extent to the village of Jobra, but after two years of success, it extended to the district of Tangail. The successful Grameen Bank project officially became the Grameen Bank in 1983- a self-regulating, member owned bank for the poor. Today Grameen bank is owned by the rural poor whom it serves. Borrowers of the Bank own $95 \%$ of its shares, while the remaining $5 \%$ is owned by the government (GB, 2010; Casuga, 2002).

While small loans to women have been the primary focus of Grameen Bank since its inception in the course of its development, it realized that new organizations are needed to be established to focus on the non-banking activities. The Grameen family of organizations was thus founded and currently eight different organizations are providing devoted activities in the following areas: venture capital, communications, Internet service provision, textiles, energy, education, and telecom.

\section{Organizational Structure}

The Grameen Bank is regulated by government ordinance of 1983. It is governed by a board of governors. The board consists of the chairperson, the managing director, and nine other members. The government appoints five of the members and the rest four are appointed by the borrower-shareholders. Since 1986 the all nine members are selected from the borrower-shareholders from a thirteen member board of the bank. The policies of the bank are approved by the government and serves as the link between the bank, the Ministry of Finance, the borrowers and other government organizations.

The Grameen Bank has a decentralized, pyramidal banking structure including lending units, centers, branch offices, area offices, zonal offices and a head office in Dhaka (Latifee, 2008). Solidarity groups are the principle lending units at the village level. The functions of the management and decision making powers have steadily been delegated to lower levels in a decentralizing process. The lowest organizational unit of the Grameen Bank is the branch office and the zonal offices, which were added up to the structure later on. Over the years, the major functions of the head office have been delegated to zonal offices. The zonal offices hand over to the area offices, the power of supervision, account management and loan approval. The head office becomes an information clearing house by this process of horizontal growth and decentralization of power. Grameen Bank has introduced five star systems in its management in order to give confidence competition and to achieve the objectives of sustainable operation and poverty alleviation. The five stars are green, blue, violet, brown and red. These are provided to the branches for a special task and to the staff for different achievement levels. The green star is for $100 \%$ repayment, the blue is for earning profit, the violet is for self-financing, the brown is for all children in school and the red is for all the members moving out of poverty (Latifee, 2008). 
In 1998 the bank encountered some repayment difficulty following a flood in Bangladesh though the structure and lending practices of the bank have proven quite successful in helping families to prevail poverty. Members of the bank stopped paying their weekly installments and stopped attending the weekly meetings with bank workers (Dowla and Barua 8,2006). So the staff and the management decided to set off some structural changes that resulted the establishment of Grameen Bank 2. Some of the changes that were put into practice in the new Grameen model include (Dowla and Barua 250, 2006):

1. A shift from group loans to individual loans.

2. Development of new products such as the Grameen pension scheme to cater the need of retires.

3. Active campaigns to collect savings from nonmembers to raise additional loan funds.

4. Allowing borrowers to borrow against their savings, unless they have payments arrears.

5. Offering only one loan product, the basic loan, rather than multiple loan products.

6. More flexible repayment schedules-installment size is variable rather than fixed.

7. New branches no longer have to borrow funds from the head office for credit disbursement. They can be self-financed by collecting funds from members and nonmembers.

8. Easing loan terms, saving requirements, and repayment conditions for beggars-the poorest of the poor.

\section{Ownership Status and outreach of Grameen Bank}

There is an ongoing question that- can microfinance reach the huge number of very poor people by maintaining sustainability? There are two different views, first- hypothetically in practice it is often tough to reach those people who are living in extremely poverty though microfinance targets all the poor clients (Rahman and Razzaque, 2000; Halder et al, 1998; Hashemi, 1997). Second, 'yes' microfinance can reach to the bottom of the poor at least a certain level (Prahalad, 2010; Dunford, 2006; Halder 2003). Figure-1 illustrates the distribution of outreach in different financial intermediaries (adopted from C.K Prahalad's Book, "The fortune at the bottom of the pyramid"). The number of people and their annual per capita expenditures are taken from The World Bank and VISA International.

Insert Figure 1 Approximately Here

In general, microfinance outreach has enlarged outstandingly in Bangladesh overtime with respect to number of clients especially the women and geographical coverage. For example, Grameen Bank has extended services to 83,458 villages, with 2564 branch offices spread across country, serving 8.32 million borrowers (cumulative no. end of July 2010). It is noted that the percentage of active women borrowers for the Grameen Bank is 97 percent, which is the commitment of GB to empowering women. Also Grameen Bank struggling members programs exclusively for the beggars which has an extended services over 112,216 beggars (GB, 2009). In the past, the women's interaction with men and their mobility were restricted in Bangladesh. The cultural behavior restrict women's mobility to go to the market, leaving them dependent on men to put their income-generating skills and knowledge into practice in terms of income generation from their assets (Holmes and jones, 2010). So, the rural women are placed in a helpless position and they also get less nutrition and less education compare with their male counterparts. In addition, the numbers of female-headed households are growing due to divorce, death of the male earner, and desertion and male migration. In contrast, it is regarded that women are the best care taker of the future generation, capable to utilize tiny amount of money and good repays as well. Realizing the issues, Grameen Bank mainly focuses on rural women, bringing about meaningful transformation in their lives by making small loans available to them for income generating activities. The figure-2 shows the number of clients of Grameen Bank overtime, which has shown the sustainability of MSPs with expanding client horizon.

Insert Figure 2 Approximately Here

\section{Operational Mechanism of GB}

Grameen Bank has integrated group organization with credit delivery to support the rural poor. Individual organizes themselves into forming small solidarity group of five. Men and women from different groups in accordance with the socio-cultural, norms of rural Bangladesh (KhandkerP.10) GB goes to the door steps in stead of clients coming to office. Clients do not require any collateral and small loans repaid in weekly installment (there are some loan products which accept monthly repayment). Clients only eligible for higher loan amount for succeeding loan (GB, 2010). Usually, when a person needs a bank loan, he/she is asked to make a five peoples group. It is a quite difficult procedure to form a group of five same-minded people and this is how to ensure group solidarity. After the group formation, the bank discusses the rules and regulations of the Grameen Bank. The group is told that all members do not get their initial loan at the same time. First, two members obtain loans and after they begin to repay the 
principles plus interest over six weeks, then the two others become eligible for loan (BG, 2010). So, individuals receives loan, but the whole group is responsible for repayment and if one member failures to pay, no other member can receive further credit. The group is also asked to make the proper utilize of the money. In this way group stress guarantees social and financial discipline among GB members

Usually, six to eight groups organized into a community called the centre, while 30-60 centers represents a branch. Each center elects a chief from the groups' chairperson. It is necessary for the group members to attend the weekly central meeting organized by the central chief. Applications for new loans as well as payment for new loans are supervised by the central chief. The loan officer/bank worker attends all the meetings, participated in the discussion, and disburses and receives money. Thus, all transactions are openly carried out and members take effective roles in conversation on progress and problem. In every village there are one or two centers. In the process of doing that they have come up with something that is popularly known is Grameen Bank as "sixteenth decision" (no dowry, education for children, sanitary latrine, planting trees, eating vegetables to combat night-blindness among children, arranging clean drinking water, etc.).

Table 1 represents the key features of Grameen Bank

Insert Table 1 Approximately Here

\section{Grameen Banks major products service delivery procedure}

Bangladeshi MSPs has introduced various kinds of financial intervention according to the necessity of various people living at different poverty levels. The following section discusses different products and services one by one i.e. loan products, saving products, insurances, remittances, education and health.

\subsection{GB loan products}

Basic loan, housing loan, higher education loan only for member's children, micro enterprise loan, village phone loan, business loan for the graduate students of GB member families and struggling members loan.

7.1.1 Basic loan: This loan is offered for 1 year and there is adaptability from 3 months to 3 years. The loan amount ranges from BTK 1000 to 5000 . The interest rate is $10 \%$ (flat)

7.1.2 Housing loan: GB established housing loan in 1984 and now it's become a very striking program. TK 15,000 (US\$ 218) is the maximum amount given for this loan to be repaid over a period of 10 years in weekly installments and the interest rate is $8 \%$. By the end of July 2010 a total amount of TK 8.95 billion (US\$ 210.38 million) has been distributed for this housing loan.

7.1.3 Education loan: This loan is given to those students who succeed in reaching the tertiary level of education and this loan covers tuition, maintenance and other expenses. The interest rate of this loan is $5 \%$ and is charged after graduation. By August' 10, 46,487 students received higher education loan, of them 44,152 students studying at various universities, 485 are studying in medical schools, 787 are studying in engineering school and 1063 are in other professional institute.

7.1.4 Village phone loan: GB offered telecommunication services in about half of the villages of Bangladesh where this kind of service has never existed before. To-date GB has provided loans to 391,442 borrowers to purchase mobile phones.

7.1.5 Micro-enterprise loan: There is no limit on the loan size. Average loan size is TK 26,976(US\$ 388.49), maximum loan taken so far is TK 1.6 million (US\$ 23,209). By the end of July a total of TK 72.77 billion (US\$ 1080.26 million) has been distributed under this category. Irrigation pump, power-tiller, transport vehicle, and river-craft for transportation and fishing are well-liked items for micro-enterprise loans.

7.1.6 Beggar's loan: The aim of this loan is to provide a respectful life style to the beggars and send their children to school and graduate into becoming a permanent GB's member. More than 112,216 beggars have attended this program and many of them already left begging. All the loans are interest free and loans can be for a very long term and even repayment installment is also very small. Struggling members are not required to give up begging, but are encouraged to take up additional income-generating activities like selling popular products at the place of begging, or door to door instead of begging.

\subsection{Savings product}

GB has various kinds of savings products. These are- compulsory saving: compulsory savings have also sub-divisions i.e. emergency fund- contribution is BDTK 5 per 1000 lent, children welfare fund- BDTK 1 per week is required to pay for members. Educations for members' children in school are also provided from this fund and run by GB groups (Hasan and Guerrero, 1997). GB pension savings- only available for GB members and staff; personal 
savings and double in 7 years-term deposits: open to all; fixed deposit with monthly income- opens to all. Total deposit in Grameen Bank stood at TK. 93.89 billion (US\$1352.11 million) by the end of August, 2010. Member deposit constituted $53 \%$ of the total deposit. Balance of member deposits have increased at a monthly average rate of $2.66 \%$ during the last 12 month (June'09 to July'10). The rate of the deposit varies from $8.5 \%$ to $12 \%$.

\subsection{Insurance products}

In microfinance sector Grameen Bank established one of the first insurance products called Grameen Kalyan. Grameen Bank has also introduced life insurance in which borrowers are not required to pay any premium. Each family receives BDTK 1,500 (US\$21.5). In Grameen Bank a total of 128,818 borrowers died so far and their families collectively received a total amount of TK 227.34 million (US\$ 4.54 million).

Non-financial services

\subsection{Training products}

Grameen Bank pays high concern to training its bank personnel and borrowers. Potential branch manager are trained for six months- general fieldwork training for five months in the branch office, and class study for four weeks. This exercise orients the bank worker to the poverty of rural life and how the poor perceive the bank (Maclssac and Wahid, 1993). There are also another kind of training for the borrowers for at least seven days where they learn about the thinking of Grameen Bank, the rules, procedures and skills of banking, the group savings program, and about the "Sixteenth Decisions". They are also taught about health, education of their children and other social responsibilities as well as how to sign their names (Hossain, 1993).

\subsection{Educational products}

Grameen Bank supports their borrowers to build up schools, pre-schools and day-care services. For the member families Grameen Bank school system also provides a full program of basic education.

\section{Financial potency}

Bangladeshi MSPs are financially sustainable as they can build up funds from different kind of sources like local banks, wholesale fund from Polli Kormo Shyakak Foundation (PKSF), international donor, savings/deposit of members, interest or service charge. PKSF was established in 1991 by the Government of Bangladesh and it has been playing a very vital role to making MSP financially independent. It refinances the NGOs giving micro-credit services to the poor in rural areas and PKSF was refinanced by government funds and also from the World Bank to continue to meet the growing financing needs of the sector. PKSF has been working as both financial intermediary and market developer and continues to be an institution central in the Bangladeshi microfinance landscape (Bedson, 2009). PKSH has helped different kinds of small MSPs to attain good levels of operational efficiency. Though, over the years in PKSF, external donor allowances have turned down in a significant pace (from $30.4 \%$ in 1997 to $7.9 \%$ in 2005) but it is worth to say that declining donor grants does not a problem of the growth of microfinance sector. For example, Grameen Bank do not allow any grants or donors from outside sources since 1998 but it is enjoying financial sustainability.

Nonetheless, Grameen Banks financial strength has been assessed on the basis of Return on Equity (ROE), Operational Self-sufficiency (OSS), and Financial Self-sufficiency (FSS) overtime (see annex 1 for more information). Operational Self-sufficiency (OSS) refers to the ability of the institutions to generate enough revenue to cover its operating costs and the Financial Self-sufficiency (FSS) refers to the institutions dependence (or lack) on subsidies for successful operation (Murdoch Dec 1999). Table 2 reveals that Return of Equity was 5.64\% for Grameen Bank in 2009 and the Operational Self-sufficiency was 102.6\%. Meanwhile, Financial Self-sufficiency was $99.21 \%$ for Grameen Bank which shows the financial power of the institute. Following three figure (Fig-3, Fig-4, Fig-5) shows the ROE, OSS, and FSS of GB. Last five years. It appears from figure(s) ROE, OSS and FSS have significantly contributed towards sustainability of GB's microfinance program.

Table 2 shows the key financial indices of Grameen Bank.

Insert Figure-3, Figure-4, Figure-5 and Table-2 Approximately Here

\section{Regulatory status}

Usually microfinance sector grows rapidly and deals with money especially the money of the poor people. That's why some kind of regulation is required for microfinance sector. Actually this is the function for the government to promulgate regulations for microfinance sector because it is government duty to keep the right of citizen safe and their money. But many MSPs have developed a code of conduct that imposed self-regulation on them. Realizing the matter, over 50 countries have implemented or are considering specific arrangement for regulation and supervision 
of microfinance either as a separate law or as amendments to the existing legal and regulatory framework in world (Mohanty, 2010).

Recently MRA has announced a guideline for NGO and MFIs in a circular issue on 10 November, 2010. The key guidelines are as follow:

o $\quad$ The maximum effective interest on loans must be 27 percent

o MSPs must pay at least 6 percent interests on mandatory weekly savings of borrowers

o NGO-MFIs can be charged maximum TK 15 for loan application forms, client admission fee, passbooks, etc.

o No deducting of money from loans should be allowed at the time of loan issuance, in the name of savings, insurance, or any other category.

o $\quad$ For micro-enterprise loans, the stamp fee must be TK 50

o Mandatory to allow at least a 15-day gap between the dates of loan issuance and first repayment installment, negotiations between lenders and borrowers, for a longer gap, have been allowed.

o Mandatory to allow at least 50 weeks time for receiving entire amounts of general loans which are issued for a period of one year

o MSP must calculate rates of interest on loans in declining balance method, in place of the existing flat rate method.

o MSP must have a specific pay structure, which must be sent to the authorities.

It is noted that Grameen Bank has registered from MRA along with other NGO-MFIs. In addition, it has adopted self-regulatory mechanism in their respective organizations.

\section{Beyond the success of microfinance in Bangladesh}

Why and how Grameen Bank model become a successful icon in Bangladesh as well as all over the world. How they met their client needs, developed relatively low cost delivery mechanisms and generated resources. Here given some of the reasons for success.

a. Lending Mechanism: It is frequently presented that the key feature of MSPs success is the group lending mechanism with individual responsibility. Therefore Grameen Bank have continuously developed their lending mechanism and now they are offering individual loan along-with group lending.

b. Accountability: The sincerity of the field officer as well as the borrowers particularly the women is one of the reasons of success.

c. Hearing women's voice: MSPs are always good listener of the voice of the poor especially women.

Accordingly, MSPs have planed and re-planed several inventive products after hearing from women.

d. $\quad$ Targeting the ultra-poor: "Ultra poor" refers to people at the very bottom of the socio-economic ladder-the poorest of the poor. So MSPs has developed a program specifically to target the ultra poor. When the ultra poor are particularly targeted as clients, conditions are often more openhanded; for example the loans may be small with no interest and no repayment timeframe.

e. Trustworthiness: MSPs have been using their previous trust for enlarging their existing programs in a successful manner. It is known that MSPs are well-organized in respect to service delivery to the urban areas. Therefore they have gained a certain degree of faith to the community. Grameen considers its relationship to be with people, not with papers. Its success or fails depending on how strong their personal relationship is with the borrowers.

f. Woman's contribution: Women have always actively participated in their local economics. They have proved their entrepreneurship and business skill for utilizing and repaying loans. Women, especially poor mothers, must divide their time between work productive role and family reproductive role and balancing all demands. There contributions have been considered as an extra income of family survival or simply to improve their living condition in male dominant society in Bangladesh. In the meantime, their spontaneous participation in microfinance activities has enlarged the opportunity of business.

g. Screening out 'bad' (non-poor and too-poor/non-viable) clients: Charging market related interest rates and client involvement in group selection. 
h. Collateral: In Bangladesh formal microfinance institutions are non-profitable and less accepted by the people because of their complicated procedures, collateral requirement and claim to corruption. At present, MSPs collateral free and simple loan approval process is become popular to get out of poverty.

i. Ensuring repayment: Group members collaborate to ensure one another's success and to guarantee loan repayment without physical collateral. Also intensive borrower supervision by field staff; peer group monitoring to ensure repayment.

j. Group pattern: It is difficult to configure a solidarity group but not as much in Bangladesh. As Bangladesh is an over populated (more than 1046 person per square $\mathrm{km}$.) country in the world. Each and every village consist a large of population. MSP conveys the vision and mission to the villagers and may start their microfinance activities without any several difficulties.

k. Diversification of product: Product diversification in microfinance that has introduced individual lending has contributed to improve the economies of scale.

1. Find availability: Soft loans are offering by the Bangladesh Bank and commercial banks to the MSPs. As well, Palli Karma-Shayak Foundation (PKSF) is working friendly with MSPs by offering financial and technical support. In this way, Bangladeshi MSPs have gained a major amount of donor grants and soft loans. This improves their scale of business and supportive surroundings facilitated financial self-sufficiency of a huge number of MSPs.

$\mathrm{m}$. Administrative efficiency: Microfinance success depends on the relation between the borrowers and the staff/organization. Administrative person need to work to work with group, transferring transaction cost to clients by maintaining a good relation. Accordingly, the sector of microfinance has realized the importance of human relationship.

n. Friendly relationship with government: MSPs have gained government reliance by their hard work, appropriate structure, assurance to improving poor people's life style particularly the women. So the government also has less interfered microfinance market that leveled to speedy growth of microfinance sector in Bangladesh.

o. Decentralization: Strong decentralization combine with widespread information and communication system is also a reason for success. The particular organization structure makes good management and transparency of Grameen Bank.

\section{Learning/lesson from Grameen Bank}

The most significant lesson can be fined out from Grameen Bank's microfinance approaches. The model of Grameen Bank can work so effectively in the rural areas even in the slum areas of the poorest countries in the world. Bangladesh is a third-world country and it can develop its own way to poverty mitigation. Some particular learning are-

- Grameen Bank has discovered micro-credit (based on their tried and tested program) is a very effective instrument to empower the poor, specially the poor women, in all cultures and economies of the world. It is cost effective, sustainable and works in a business-way. It gives a poor person a chance to take their own destiny into their own hands and get out of poverty with their own efforts.

- Credit access to poor is a very vital and key part of any socio-economic development of the poor.

Definitely, Grameen Bank's innovation of collateral free group lending has shown success in Bangladesh as well as some other parts in the world.

- The importance of appropriate training and orientation of the field staff is also important for successful accomplishment of a project which may be followed by other microfinance institutions. It is already proven by GB that poor can utilize loans and repay them if effective procedures and relationship are maintained and established.

- Lack of collateral should not stand in the way of providing credit to the poor as the poor can utilize loans and repay them if effective procedures for bank transactions with them can be established.

- $\quad$ The process of reaching the poor of MSPs is very effective and with the sense of concern and belief in the strengths of the poor especially women.

- A good learning from Grameen is taking the bank to the people rather than people to the bank.

- The credit plus-plus option has given a lot of benefit and has believed more appropriate towards poverty reduction.

- GB's decentralize organization pattern combined with extensive information and communication systems are lessons for other development patterns/organizations. 
- GB's service delivery mechanism can be applied to other developing countries with adaptation.

- In Bangladesh, there is a competition among microfinance service providers particularly key players so products keep improving. In addition, government has also several collaborative programs in certain direction towards poverty alleviation. The government has gained full point full points for poverty reduction with proper policies and guidelines.

- Microfinance is not simple. People have played in their individual role to make the sector profitable.

\section{Future challenges}

Major success have been achieved by large MSPs in Bangladesh though innovative approaches, diversified products and services, financial strengths and improving regulatory environment. However, they sector may find out some challenges in near future. Some of them are-

- $\quad$ Enhancing the resources versus reaching the poor clients: Near future the number of borrowers will increase and now days MFIs have lack of sufficient resources to finance the growing number of borrowers. In order to mitigate this problem, MFIs may need to increase their interest rate which discourages the poorest clients and thereby encountering the borderline poor.

- In spite of success of large MSPs, a lot of small MSPs are unable to run successfully because of commercialization, lack of adequate human, financial and technical resources.

- Higher repayment rate is always a indicator of success of MSP. However, there is a obligation that loan officers may use their superior power to pressure clients to pay the weekly meetings, sometimes using techniques that come close to social collateral.

- Smaller versus larger loan sizes: It has been seen that MFIs like bigger loan sizes in order to increase the level of financial sustainability. This may lead to worsening repayment performance and exclusion of the poorest.

- Microfinance is an effective tool towards poverty reduction but there is question remains whether such an approach is comprehensive to poverty reduction if there is a lack of connection in production as well as infrastructure and market development process.

- $\quad$ About 3000 MSPs have been running in Bangladesh at local, regional and national level. These micro-credit suppliers provide credit without taking care of previous lending history like whether she receives loans from other MFIs or not. So, there is a concerning trend of multi-loans of borrowers which fell them difficulties to repay and thus create over-indebt ness.

- Increase in client-base versus sustainability of MFIs: It is necessary to make the number of clients higher within that branch to achieve financial sustainability of that MFI branch. This may imply investment in less portfolio activities and reducing the impact on poverty mitigation and reducing the demand for loans.

- $\quad$ Settle down the impact of poverty reduction of such microfinance programs in Bangladesh is a difficult task. Simultaneous programs have been implemented by government and other development patterns. So, it is the combination impact of the development intervention by MSPs, development organization and government.

- $\quad$ There has been some criticized about the group lending model of Grameen Bank. Group stress presses only for repayment but this may not supportive at the time of production failure.

- Despite flexible initiatives in recent years, there remains concern of exclusion of the poorest and remote areas in Bangladesh. It is reported by PKSF that the coverage of micro-credit operations is absent in the more remote and less populous districts of the country's north and southwest part.

Criticisms are good as long as they are constructive. Leading to further improvement of approaches of adapted.

\section{Applicability}

Bangladeshi MSP has proven their applicability in many developing countries. For instance, Grameen Bank approach has widely been replicated in many developed and developing countries in the world include- China, India, Pakistan, Sri Lanka, African countries, USA, Canada and Germany, has been applying the approach according to their countries suitability. China's most of microfinance service providers have been using GB plus something of their own kind of approach suiting to their own need. Before adapting microfinance approach in a certain country take is that it need well understood and some flexibility is adapted according to the particular socio-cultural background.

\section{Conclusion}

"Poverty" and "Poverty Alleviation" are frequently heard buzzwords today and micro-credit programs have a strongly positive relationship with poverty alleviation. It is not a simple task to improve the livelihood of the poor 
people. The geographical location of the poorest and the environment of the border in which they operate also make it more difficult to help them. For illustrate, while the poorest can be found in urban areas, most of the poorest in Asia are concentrated in rural areas where basic physical infrastructure is highly inadequate (Haan and Michele, 1998). However, Grameen Bank along with other MSPs has been able express the outcome of microfinance towards sustainable development for the rural poor in Bangladesh. Without the spontaneous participation of the Bangladeshi people especially the women, microfinance success could not be achieved. In addition, the way of financing poor people in an alternative way and new products and services development have lead to this success. The effective and efficiency management skill, innovation approach and decentralization institution patterns are also remarkable.

Typically, Grameen Bank offers small loans to the poor people who do not have any physical collateral and deprive of access to credit offered by regular private banks. GB gives individual loans to villagers in group of five and the whole group is jointly liable for repayment. This creates social pressure and solidarity, which seems to work well in a society where social networks are often of vital importance.

Finally, the liberal policy of Bangladeshi government to MSP as well as establishment of PKSF has shown a rapid growth of microfinance sector in Bangladesh. PKSF is a reliable source for refinancing the MSP specially the small MSP. In contrast, Microfinance Regulatory Authority (MRA) is trying to build up the microfinance sector stable by keeping clients interest and service provider interests as well. The recent MRA circular on ceiling effective interest rate along with other guidelines can be regarded as a first step to construct the sector in a formal regulatory framework.

\section{References}

ADB. (1999). A study of NGOs Bangladesh. Asian Development Bank. Bangladesh.

Bedson, J. (2009). Microfinance in Asia: Trends, Challenges and Opportunities. The Foundation for Development Cooperation, Queensland, Australia, available at:http://www.bwtp.org/files/MF_Trends_Challenges_Opportunities_ELECTRONIC.pdf.

Casuga M.S. (2002). Documentation of product development process in selected MFIs-review of literature. Microfinance council of the Philippines. Inc. Philippines.

DFID. (2010). DFID's programs in Bangladesh Third report of Session 2009-10 House of Commons International Development Committee, 1

Dunford, C. (2006). Evidence of Microfinance's contribution to achieving the Millennium Development Goals. Freedom from Hunger. USA, available at http://www.microcreditsummit.org/papers/Workshops/17_Dunford.pdf.

GB. (2010). Grammen Bank. banking for the poor. http://www.grameen-info.org/index.php?option=com_frontpage\&Itemid=68.

GB. (2009). Grameen Bank. banking for the poor. annual report. 2009.

GB. (2008). Grameen Bank. banking for the poor. annual report. 2008.

GB. (2007). Grameen Bank. banking for the poor. annual report. 2007.

GB. (2007). Grameen Bank. banking for the poor. annual report, 2006.

Hasan M.K. and Luis Renteria-Guerrero. (1997). The experiences of the Grameen Bank of Bangladesh in community development. International Journal of Social Economics. 24 (12):1488-1523. http://dx.doi.org/10.1108/03068299710193949

Holmes R. and N.Jones. (2010). Rethinking social protection using a gender lens. ODI working paper series-320. Overseas Development Institute (ODI). UK.

Hossain, M. (1993). The Grameen Bank: its origin, organizations and management style. Boulder co: The Grameen Bank.

INAFI. (2007). INAFI Asia Mapping on Microfinance and Remittance. International Network of Alternative Financial Institution. INAFI Asia Secretariat Dhaka. Bangladesh. November. 2007 available at http://www.inafiasia.net/download/new/Microfinance\%20\&\%2020Remittance/INAFI\%20Asia\%20Mapping\%20on $\% 20$ Microfinance $\% 20 \& \% 20$ Remittance.pdf.

Jasen G G. James L.P. (1998). The Grameen Bank in Bangladesh: Helping poor women with credit for self-employment. Journal of Community Practice (The Haworth Press. Ins.) 5, pp. 103-123 
Latifee. H.I. (2008). Financial Inclusion: The experience of Grameen Bank. paper presented at the Conference on Deepening Financial Sector Reforms and Regional Cooperation in South Asia held at the Gulmohar Hall. India Habitat Centre. Lodi Road. New Delhi-110003. India. November 06-07, 2008.

Maclsaac, N. \& Wahid, A.N.M. (1993). The Grameen Bank: Its institutional lessons for rural financing. In A.N.M.Wahid(Ed.). The Grameen Bank. Poverty relief in Bangladesh (pp. 191-209).Boulder. Co: Westview Press.

MIFA. (2009).Bangladesh Microfinance and financial sector diagnostic study final report-2009. MIFA-promoting microfinance in Asia. IFC. Washington Dc. USA.

Dowla. Asif and Dipal Barua. (2006). The Poor Always Pay Back: The Grameen 2 Story. Bloomfield: Kumarian Press Inc.

MIRB. (2009). Microfinance Industry Report Bangladesh. The Banking with the Poor Network in collaboration with the SEEP Network available at: http://www.bwtp.org/files/MF_Industry_Report_Bangladesh_ELECTRONIC.pdf.

(Accessed 20 July, 2010).

Morduch, J. Dec.(1999). The microfinance promise. Journal of Economics Literature.37 pp 1569-1614. http://dx.doi.org/10.1257/jel.37.4.1569

MRA. (2010). NGO-MFIs in Bangladesh. Micro-credit Regulatory Authority. Dhaka. Bangladesh. Vol.6.

MRA. (2009). NGO-MFIs in Bangladesh. Micro-credit Regulatory Authority. Dhaka. Bangladesh. Vol.5.

Prahalad.C.K. (2010). The fortune at the bottom of the pyramid-eradicating poverty through profits. Fifth anniversary addition. Wharton School Publishing.

Rahman Atiur. Razzaque Abdur. (2000). On reaching the hard core poor: some evidence on social exclusion in NGI programs: The Bangladesh Development Studies. 36, pp 1-36.

Rashid. L.. Khandakar. M.H.. Jamsheduzzaman. and Ranjit. K.R. (2010). Microfinance Regulations in Bangladesh: Development \& Experience. Paper presented in the International Conference on Microfinance Regulations: Who Benefits? arranged by the Micro Credit Regulatory Authority in Bangladesh. 15-17 ${ }^{\text {th }}$. March, 2010. Dhaka. Bangladesh.

UN. (2006). Microfinance for Poverty Reduction: Building Inclusive Financial Sectors in Asia an the Pacific Economic an Social Commission for Asia an the Pacific Development Papers No. 27. UN. Economic an Social Commission for Asia an the Pacific. New Work.

Table 1. Key features of the Grameen Bank

\begin{tabular}{|l|l|}
\hline Particular & Grameen Bank \\
\hline Group & 5 members \\
\hline Group function & Weekly conference, allocation of information and conversations \\
\hline Loans & Group and individual \\
\hline Lending decisions & Area office \\
\hline Approval Procedure & $\begin{array}{l}\text { After experiencing with "sixteenth decisions" application is accepted and approved in the central } \\
\text { meeting, two members obtain loans and after they begin to repay the principles plus interest over six } \\
\text { weeks, then the two others become eligible for loan }\end{array}$ \\
\hline Liability & Group and individual \\
\hline Collateral & Free, no group members are accountable to pay on behalf of other \\
\hline Service & Door steps \\
\hline Repayment & $\begin{array}{l}\text { Usually, weekly in the central meeting; in addition field staff sometimes visits borrowers house incase } \\
\text { of failure to pay }\end{array}$ \\
\hline Interest rate & Varies (10-15\%) flat rate \\
\hline Supervision & Guided about the proper use of the loan and knowing 16 GB's decisions \\
\hline
\end{tabular}


Table 2. Key financial indices of Grameen Bank

\begin{tabular}{|l|l|}
\hline Particular & GB \\
\hline Disbursement (in million dollar) & 1151 \\
\hline Outstanding (in million dollar) & 792 \\
\hline Repayment Rate (\%) & 97 \\
\hline Return of Equity (ROE \%) & 5.64 \\
\hline Operational Self-sufficiency (OSS \%) & 102.63 \\
\hline Financial Self-sufficiency (FSS) & 99.21 \\
\hline Savings (in million dollar) & 1205.95 \\
\hline Net profit (in million dollar) & 5.38 \\
\hline
\end{tabular}

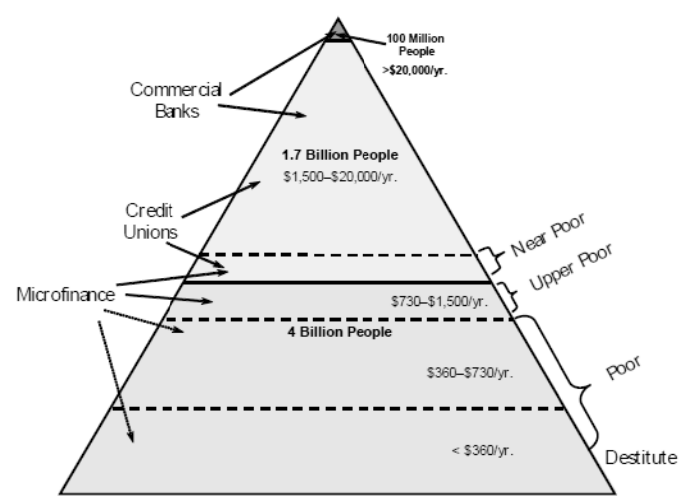

Figure 1. Outreach of different financial intermediaries in pyramid

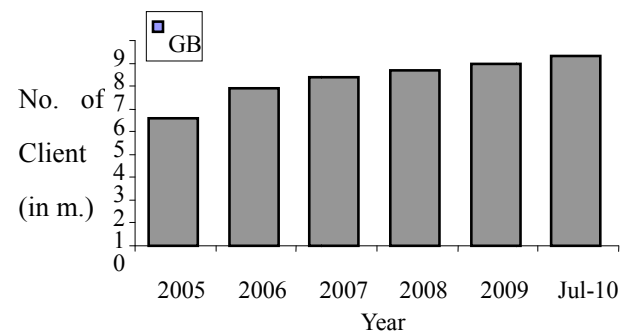

Figure 2. No.of clients of GB during 2005 to July 2010

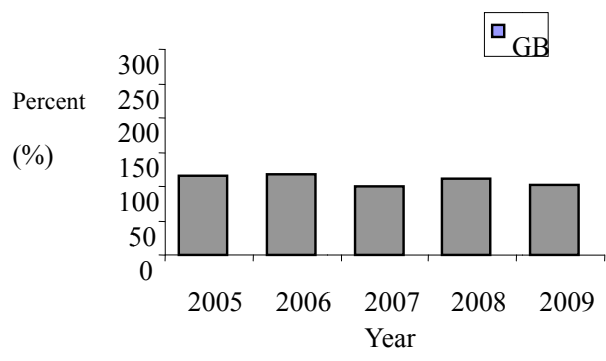

Figure 4. OSS of GB during 2005-2009

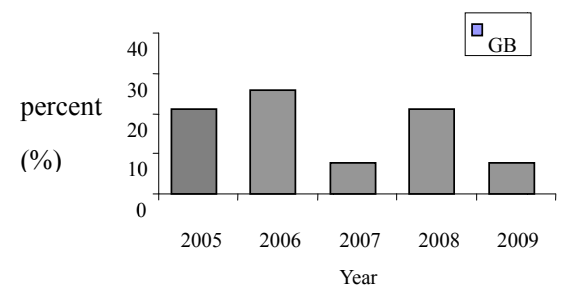

Figure 3. ROE of GB during 2005-2009

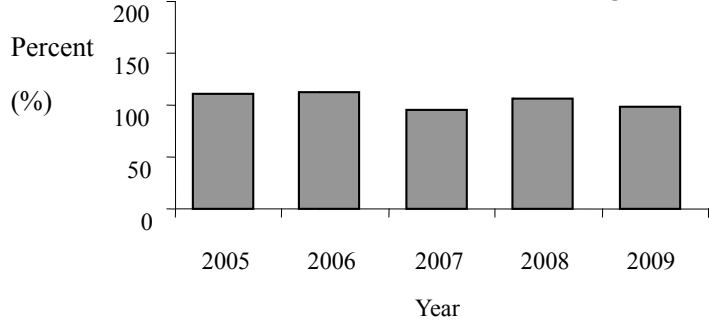

Figure 5. FSS of GB, during 2005-2009

\section{Annexure}


Annex 1. Financial portfolio of Grameen Bank

\begin{tabular}{|l|l|l|l|l|l|}
\hline Item & $\mathbf{2 0 0 5}$ & $\mathbf{2 0 0 6}$ & $\mathbf{2 0 0 7}$ & $\mathbf{2 0 0 8}$ & $\mathbf{2 0 0 9}$ \\
\hline No. Branch offices & 1735 & 2319 & 2481 & 2539 & 2562 \\
\hline Loan disbursed (in million US\$) & 612 & 727 & 731 & 906 & 1151 \\
\hline Outstanding (in million US\$) & 427 & 476 & 530 & 646 & 792 \\
\hline Current performing loan(in million US\$) & 416 & 463 & 509 & 623 & 757 \\
\hline Overdue loan(in million US\$) & 7.28 & 8.51 & 14.91 & 17.99 & 20.82 \\
\hline Portfolio growth rate (\%) & 39.66 & 18.32 & 9.26 & 22.22 & 23.2 \\
\hline Return on Equity (ROE \%) & 21.22 & 25.83 & 1.79 & 21.21 & 5.64 \\
\hline Operational self sufficiency (OSS \%) & 115.65 & 117.41 & 101.02 & 112.2 & 102.63 \\
\hline Financial Self sufficiency (FSS \%) & 110.4 & 112.28 & 94.84 & 106.07 & 99.21 \\
\hline Cost per borrower (US\$) & 8.27 & 7.78 & 8.87 & 10.29 & 12.89 \\
\hline Net Profit (in million US\$) & 15.20 & 20.00 & 1.56 & 18.99 & 5.38 \\
\hline Portfolio at risk ratio (PAR \%) & 2.57 & 2.69 & 3.88 & 3.67 & 4.39 \\
\hline Capital adequacy ratio (\%) & 13.41 & 14.38 & 12.43 & 12.02 & 10.65 \\
\hline Savings (in million US\$) & 482.92 & 634.27 & 758.92 & 940.09 & 1205.95 \\
\hline
\end{tabular}

Source: Grameen Bank annual report, 2006, 2007, 2008 and 2009 